\title{
ZPRÁVA O ČINNOSTI MATICE ČESKÉ V ROCE 2021
}

Činnost Matice české byla i v roce 2021 výrazně poznamenána nepř́znivou epidemiologickou situací, která způsobila dlouhodobé uzavření objektů Národního muzea pro veřejnost a tím znemožnila pořádání popularizačních přednášek a dalších programů nejen pro členy. I přes tuto nepřízeň doby se podařilo uskutečnit několik projektů, zvláště zaměřených na připomenutí dvoustého výročí narození Karla Havlíčka Borovského.

V květnu byla připravena na zámek v Malči u Chotěboře, který je v majetku Václava Macháčka-Riegra, výstava pod názvem Směle kupredu! Svět Karla Havlička. Textově ji zajistili Magdaléna Pokorná a Dalibor Dobiáš. Obrazově pak za využití reprodukcí sbírek Národního muzea a Památníku národního písemnictví Yvetta Dörflová, Lubomír Sršeň a Pavel Muchka. Vedle 12 panelů zde bylo až do konce srpna možné spatřit Havlíčkův pracovní stůl z redakce Národních novin nebo knižní fragment osobní knihovny tohoto nejvýznamnějšího novináře 19. století. Výstava byla koncipována jako putovní, proto se po skončení na zámku v Malči přesunula do Havlíčkova Brodu. Objevila se postupně také v Sobotce, Hradci Králové, Poděbradech, Rakovníku, Neratovicích, Ríčanech, Klatovech, Plzni, Boskovicích, Duchcově, Varnsdorfu. V roce 2022 bude rozšířená verze výstavy instalována na celou sezónu ve Středočeském muzeu v Roztokách, objeví se také v Ostravském muzeu nebo v městských knihovnách v Dobříši, České Lípě a ve Slaném. Nebývalý zájem o výstavu byl podpořen spoluprací s Knihovnickým institutem při Národní knihovně ČR. Matici českou tak navnadil pořádat podobné putovní výstavy u příležitosti výročí jiných osobností české literární kultury.

Havlíčkovi byl věnován i podzimní přednáškový cyklus v Historické budově Národního muzea. Byl zahájen dne 4. listopadu 2021 vystoupením Luboše Velka pod názvem Karel Havlićek a volebni kultura roku 1848. Následující přednášku dne 11. listopadu měla Magdaléna Pokorná pod názvem Karel Havlíček a jeho reflexe evropské politiky. Tematicky zaměřený cyklus ukončil dne 18. listopadu ředitel Muzea Vysočiny Havlíčkův Brod Michal Kamp přednáškou Podoby Karla Havlička v české společnosti 1856-1989.

$\mathrm{V}$ rámci dlouholetého projektu Matice české, jehož cílem je připomínání osobností české národní kultury ve formě informačních panelů, proběhlo dne 31 . července slavnostní odhalení panelu o životě a díle Jana Karla Rojka (1804-1877) v Budyni nad Ohří, kde je také pohřben. Spolupráce s vedením města byla skutečně př́kladná, trvale vykazující hluboký zájem o kulturní dědictví města.

Důležitou roli v matiční činnosti i dnes zaujímá nakladatelská činnost. Byly dokončeny dvě publikace, které rovněž

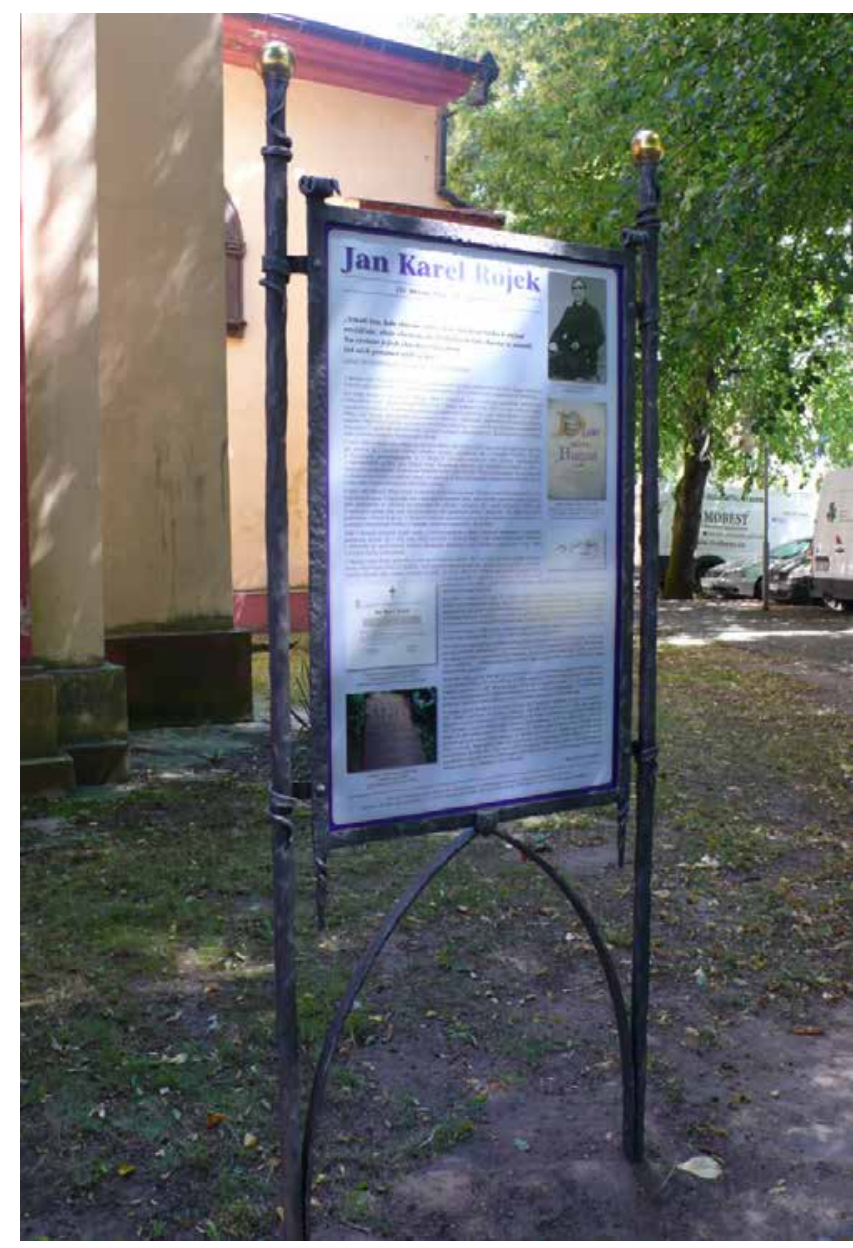

Obr. 1. Informační panel Jana Karla Rojka je umístěn před kostelem sv. Václava na Mírovém náměstí v Budyni nad Ohří. Foto: Pavel Muchka.

obsahově korespondují s hlavním zaměřením Matice české a Národního muzea. Kniha Niny Milotové o hoře Rípu v 19. století a vícesvazkové dílo Lubomíra Sršně Malované závěsné portréty ze sbírek oddělení starších českých dějin Národního muzea. Knihy budou slavnostně představeny v první čtvrtině příštího roku.

V říjnu byl obnoven cyklus prezentací Ze života sbirek Národního muzea, který se snaží představit prostřednictvím kurátorů sbírkové a projektové bohatství Národního muzea. Hanuš Jordán prezentoval část sbírek divadelního oddělení (fotografie, dokumenty k činnosti cirkusů a varieté). S předměty, které jsou spojené s působením početné komunity Čechů na Volyni, seznámil př́itomné Ondřej Štěpánek z oddělení novodobých českých dějin. V listopadu následovaly 

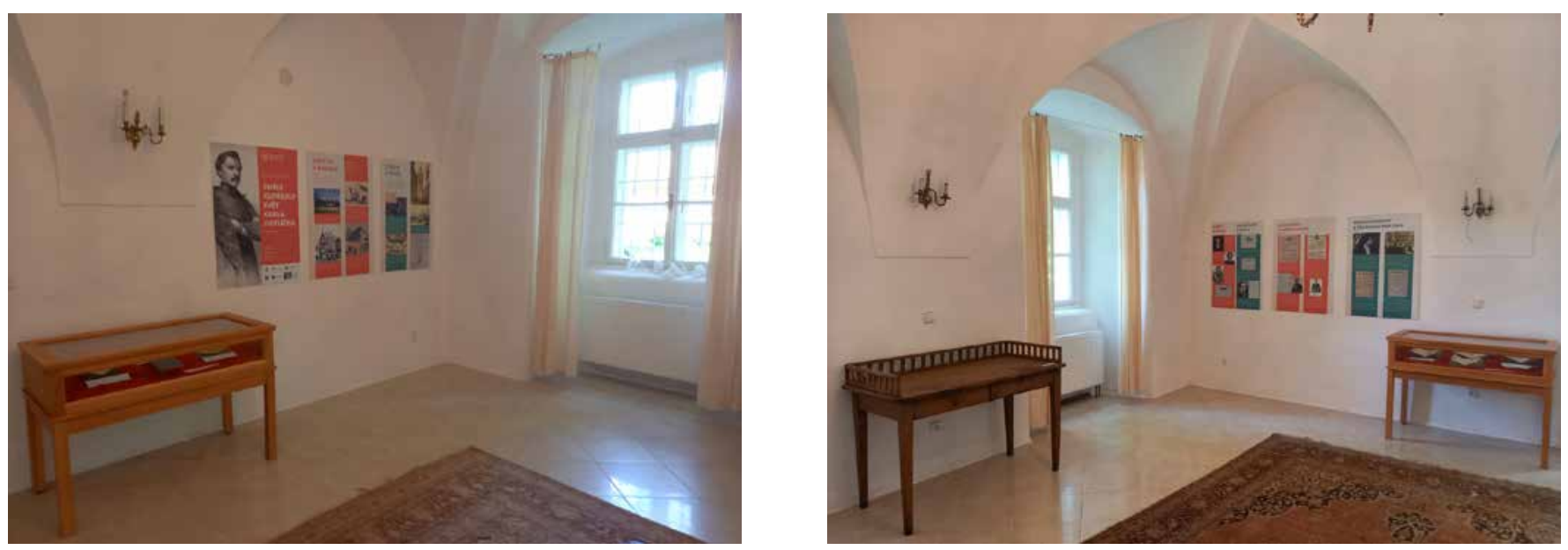

Obr. 2a a 2b. Výstava u př́ležitosti dvoustého výročí narození Karla Havlíčka zde byla díky laskavosti majitele zámku v Malči Václava Macháčka-Riegra otevřena od 29. května do 29. srpna 2021. Foto: Pavel Muchka.

přednášky o sbírce textilu a oděvních doplňků oddělení starších českých dějin Národního muzea (Vanda Marešová), největší sbírce loutek v ČR (Lenka Šaldová), cedulích a plakátech divadelního oddělení (Markéta Trávníčková) a sbírce $\mathrm{k}$ dějinám trampingu $\mathrm{v}$ etnografickém oddělení. $\mathrm{V}$ prosinci byly uspořádány ještě prezentace fotoarchivu oddělení tělovýchovy a sportu (Karolína Snellgrove), numismatických sbírek (Jan Boublík), antických památek v Národním muzeu (Helena Svobodová) a národopisných sbírek (Monika Tauberová). Všechna tato vystoupení budou trvale online př́stupná na YouTube a webových stránkách Společnosti Národního muzea.

Pro členy byly připraveny kulturně poznávací zájezdy se zaměřením na literární pamět’ míst. $V$ květnu první zájezd směroval na vernisáž matiční „havlíčkovské“ výstavy do Malče a Havlíčkovy Borové. V červnu ve spolupráci $\mathrm{s}$ opatem tepelského kláštera Filipem Zdeňkem Lobkowiczem jsme navštívili Teplou a okolní sakrální stavby. V červenci jsme nejen za Jaroslavem Haškem vyrazili do Lipnice nad Sázavou a okolí. Srpnové cestování směřovalo na Lounsko za Boleslavem Jablonským a Pardubicko za Julií Havlíčkovou. Poslední dva výlety se uskutečnily v záríí, a to na Rokycansko, Mělnicko a Mladoboleslavsko.

V prosinci Matice česká ve spolupráci se Společností ochránců památek ve východních Čechách připomenula 190. výročí narození významného českého novináře a politika Julia Grégra v jeho rodném Březhradu u Hradce Králové. Jako trvalá Grégrova připomínka zde vznikla originální kovová lavička s motivem stránek Národních listů.

Na rok 2022 plánuje Matice česká uskutečnit tradiční jarní a podzimní přednáškové cykly, řadu exkurzí a výletů nejen pro členy. Nebudou chybět ani prezentace nových matičních knih a nové informační panely v regionech.

\section{Pavel Muchka}

Knihovna Národního muzea

oddělení knižní kultury

Vinohradská 1

11000 Praha 1 